includes Sphenophyllum thoni, S. oblongifolium, Pecopteris unita, and $P$. arborescens-all members of the European Uppermost Carboniferous and Lower Permian floras. A few of the "northern" species also occur in the Carboniferous or Lower Permian flora of Sumatra (a flora resembling those of Europe, not those of Gondwanaland). Of considerable interest also is the presence of a number of species also known from the Shihhotse series of China. The age of the Chinese flora is regarded as Middle or else Lower Permian-the Wankie fossils suggest the older age.

This correlation of the Glossopteris flora with the Upper Carboniferous or Lower Permian of Europe comes at a time when the Gondwanaland floras are the subject of a controversy arising from Schuchert's view that the Permo-Carboniferous glaciation occurred in the Middle Permian and that the Glossopteris flora was of Middle to Upper Permian or even of Triassic age. The recent close study of the Gondwanaland floras has shown that several are older than was hitherto thought-for example, the so-called Rhaetic flora of the Karroo is of Middle Triassic age or even older.

T. M. H.

Type Ammonites, VII. By the late S. S. Buckman. With Editorial Note, Chronological and other tables, and index by $\mathrm{A}$. Morley Davies, D.Sc. Parts lxxi-ii (combined). pp. 15-78. 1930.

TN this, the final part of Buckman's Type Ammonites, Dr. Morley 1 Davies has provided a well-planned series of tables and indexes which greatly facilitate the use of the preceding text and plates, and are indeed practically indispensable. We are asked to state that publication and sale of this work has now been taken over by Messrs. Thomas Murby and Co., 1 Fleet Lane, Ludgate Circus, E.C. 4.

\title{
OBITUARY.
}

\section{Percy Albert Wagner, B.Sc., M.E., D.Ing., F.G.S., etc.}

On the 11th November, 1929, South Africa lost at the comparatively early age of 44 years her most brilliant geologist, Dr. P. A. Wagner. He received his training at the South African School of Mines, at Freiberg in Saxony, and at Heidelberg University and, returning to South Africa, spent a short while on the Geological Survey of the Transvaal, was thereafter for some years in the employ of the De Beers Consolidated Mines, and was subsequently appointed to the Union Geological Survey. A few years ago he relinquished Government service to do consulting work for the Becker Trust of Johannesburg, mainly in connection with diamonds, platinum, chromite, and asbestos. 
While studying in Germany his attention was directed to the kimberlite occurrences, which at a much later date resulted in that fine and still standard volume, The Diamond Fields of Southern Africa, 1914, in which this wide and fascinating subject has been ably treated from the viewpoint not only of the practical mining engineer, but of the mineralogist and petrologist. On the annexation of German South-West Africa he was commissioned by the Union Government to compile a record of the geology and mineral resources of that territory, and brought together in a valuable memoir (1916) the scattered information relating to that vast region.

Although his journeyings through Southern Africa were extensive, the amount of regional mapping done by him was rather limited, since his interests centered in the economic side of geology, which resulted in numerous papers and memoirs, mainly of an official character, on the mineral occurrences of South Africa, more particularly those of diamonds, iron, tin, and platinum. The most recent survey of the resources of the Union, that in the Handbuch der regionalen Geologie VII $7 a$ (1929), was from his able pen.

From among his many writings can be singled out The MutuëFides-Stavoren Tinfields(1921), Report on the Crocodile R. Iron Deposits (1921), The Pretoria Salt-pan (1922), On Magmatic Nickel Deposits of the Bushveld Complex in the Rustenburg District (1925), and The Iron Deposits of the Union of South Africa (1928). Finally comes his outstanding volume on The Platinum Deposits and Mines of South Africa (1929), the appreciative reviews of which he was unfortunately not spared to enjoy. For several years he acted as Associate Editor of Economic Geology.

A keen observer and careful investigator, his writings are characterized by many penetrating ideas, and certain of his views on ore genesis-more particularly those on the origin of the magmatic sulphide ores-form a highly important contribution to literature, while his extended researches into the structure and petrography of the Bushveld Igneous Complex have materially added to our knowledge of that enormous intrusive.

Compelled during the past few years to crowd much writing into the brief moments snatched from a busy career, he seems to have undermined his constitution, and fell a victim to enteric fever contracted in the field. Unselfish in character, charming in manner, enthusiastic in discussion, and friendly in debate, his untimely death is sadly felt by a wide circle of friends and will be still more deplored by geologists the world over.

A. L. d. T. 